\title{
Evolution towards meromixis of Lake Iseo (Northern Italy) as revealed by its stability trend
}

\author{
Walter AMBROSETTI* and Luigi BARBANTI \\ CNR Institute of Ecosystem Study, Largo V. Tonolli 50, 28922 Verbania Pallanza, Italy \\ *e-mail corresponding author: w.ambrosetti@ise.cnr.it
}

\begin{abstract}
Temperature, oxygen concentration, conductivity and ionic composition of the water of Lake Iseo $\left(z_{\max } 251 \mathrm{~m}\right)$ between 1978 and 2003 were used to analyze the lake's evolution towards meromixis, through stability calculations following Walker (1974). Total, thermal and chemical stability is assessed, both as an integrated quantity on the whole water column and in its vertical distribution. The results show an increase over time of total stability in winter, caused by the increase of solutes present in the deep layers, the result of the isolation of these layers due to a lack of complete vertical mixing, and in summer by an increase in the thickness of the surface water layer involved in the annual heat exchange. It emerges clearly that the anoxia of the deep layers, which first occurred in 1994, is related to the increase in the solutes present in the deep hypolimnion, and that the solutes, via chemical stability, are related to the depth of the vertical winter mixing. In addition, the high density present in the deep layers due to the solutes also prevents them from being oxygenated by hydro-meteorological mechanisms resulting from the inflow of river water to the deep layers, mechanisms which are common in deep lakes like Iseo. The vertical distribution of the stability values makes it possible to identify the water layers that present the greatest resistance to mixing, and to evaluate how their volume has continually expanded over the years, so that now more than 50\% of the lake volume is affected. As a result the deep layers are increasingly stable and isolated. The vertical distribution of the chemical stability reveals that at the end of winter Lake Iseo still has below $50 \mathrm{~m}$ a level with a chemical stability of more than $0.02 \mathrm{~J} \mathrm{~m}^{-2}$, which means that a full circulation cannot occur.
\end{abstract}

Key words: deep lake, meromictic lake, oxygen, ionic composition, conductivity, vertical mixing, thermal-chemical-total stability

\section{INTRODUCTION}

One of the most important hydrodynamic processes characterizing the deep subalpine Italian lakes - as is the case in all large water masses on earth, and certainly those in temperate zones - is indisputably the vertical mixing of the water at the end of the limnological winter. This process can have major physical, chemical and biological effects, on the whole lake ecosystem.

The subalpine lakes (Maggiore, Como and Garda), with depths between 250 and $410 \mathrm{~m}$, are classed thermally as warm monomictic lakes; nevertheless, their great depth means that the vertical winter homogenization is not always completed before the new stratification phase begins. The recent history of these lakes shows that the processes of holomixis and oligomixis have alternated - albeit with the prevalence of the latter - at least since the beginning of the $80 \mathrm{~s}$, with an almost complete persistence of only partial circulations. This is due primarily to the winter climatic conditions of the last twenty years (at least), which have seen a progressive warming of the atmosphere and a reduction in wind (Ambrosetti et al. 2003a).

In common with the other deep subalpine lakes, Lake Iseo was oligotrophic even in the recent past; this is documented in the earliest limnological studies of the lake (Bonomi 1967), and more recently by sediment studies (Guilizzoni et al. 1982, 1983), diatom studies
(Marchetto \& Bettinetti 1994), and research into the lake's trophic state (Garibaldi et al. 1995; Garibaldi et al. 1997; Salmaso et al. 2003). Anoxia in the deep layers was observed for the first time in 1994, along with an increase in density, which became more marked in succeeding years; with this trend, the vertical winter mixing of the water was no longer able to make up the oxygen deficit caused by eutrophication .

This study was designed to monitor the trophic evolution of Lake Iseo as its waters gradually become meromictic, taking account of variations in some physical aspects and, especially, of stability as conceived by Walker (1974); this is defined as the work required to mix a thermally stratified lake until it reaches new isothermal conditions under adiabatic conditions. This is one of the parameters which Hutchinson (1957) described at the time as being of limited interest and also somewhat abstruse, but it can be used and may be regarded as of prime importance in analyzing certain physical phenomena which occur in lakes. Our intention is to prove that a complex hydrodynamic phenomenon like the annual cycle of winter convective mixing in a lake can be described in quantitative terms. In fact, in the same way as the parameter of Birgean work, and more than those of water temperature and dissolved salts along the vertical, this parameter makes it possible to quantify the hydrodynamic processes occurring at the various levels within the water mass. 


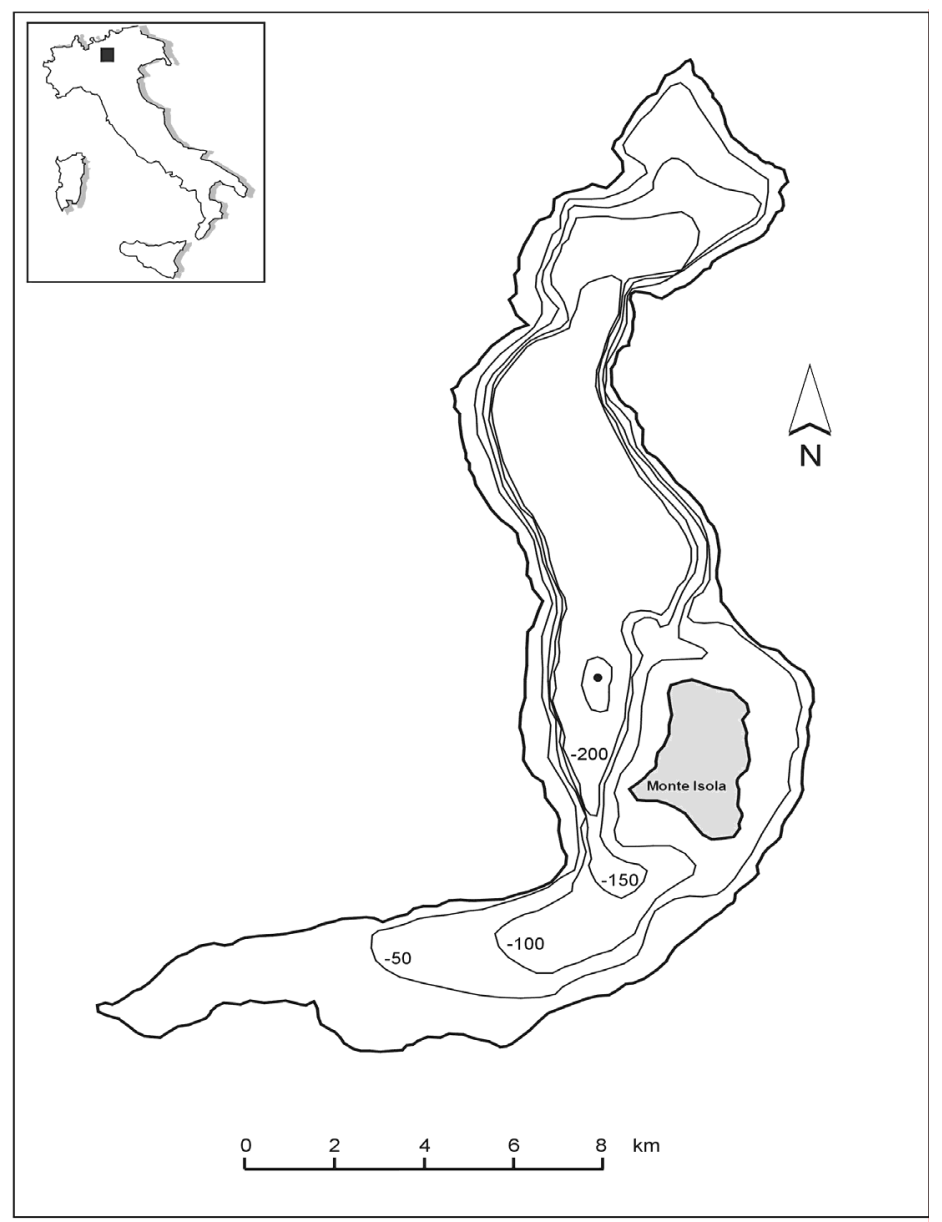

Fig. 1. Bathymetric map of Lake Iseo. The lake is located south of the Alps in Northern Italy.

The evolution in time of stability in Lake Iseo over the last 25 years will be analyzed in relation to the solute and dissolved oxygen concentrations, as well as the water temperatures on the column, occurring in winter and early spring, i.e. the moment when convective mixing ought to reach its maximum depth. This is the critical moment for deep lakes, as it is at this time that their internal hydrodynamics are conditioned for the rest of the year.

In fact, previous studies, such as those by Johnson et al. (1978), Johnson \& Merritt (1979), Ambrosetti \& Barbanti (1986), Bowling (1990) and Bowling \& Salonen (1990), suggested using standard parameters such as thermal stability and Birgean work to quantify the energy of a lake and to compare the physical backgrounds of a variety of lake environments, and also as parameters for assessing limnological work. Other researchers, such as Biswas (1977) on Lake Ghana, Viner (1984) in New Zealand, Loranger (1988) in western USA, Kling (1988) in Cameroon, Ferris (1988) in the Antarctic, Henry (1989) in Brazil, Bowling \& Salonen (1990) in Finland, Mackey (1991) in Australia, Geller (1992) in Chile, Kyensmo (1994) in Norway, have tackled the problem of thermal stability in lakes. However, none of these studies made a conclusive analysis of the vertical stability distribution over a long period. Walker (1974) introduced parameters to define the stability of six meromictic lakes in central Washington, distinguishing "thermal" from "chemical" (or meromictic) stability. More recently Wuest et al. (1996) quantified the stability within the water column of the deep basin of Lake Malawi as a function of conductivity, temperature, dissolved solids and nonionic constituents.

These parameters can be assessed as values integrated on the whole water column, which can allow a comparative analysis with other lakes (Ambrosetti \& Barbanti 2002b), but they can also be analyzed in their vertical distribution, i.e. along the water column, which permits a check of the hydrodynamic mechanisms occurring within the water mass of each lake at various levels, both during the summer stratification and at the time of the winter mixing.

\section{MATERIAL AND METHODS}

Lake Iseo (Fig. 1) after Garda, Maggiore and Como is the fourth of the great lakes of the Italian subalpine lake district. It has a surface area of $61.8 \mathrm{~km}^{2}$, a volume of $7.6 \mathrm{~km}^{3}$, a maximum depth of $251 \mathrm{~m}$ and a mean 
depth of $123 \mathrm{~m}$; its theoretical water renewal time is 4.1 years. The chemical and physical limnological data used in this study refer to samples taken at the point of maximum depth in the lake at various times between 1978 and 2003 by the Department of Environmental Science at the University of Milan and by the Italian Institute of Hydrobiology (now Institute for Ecosystem Study) of Pallanza. Up to 1993, measurements and sampling were performed in spring and autumn, but the frequency has been monthly since 1994 (as it also was in 1978). The water samples were collected in Van Dorn bottles; dissolved oxygen was measured using a multiparametric probe, and regular control measurements of $\mathrm{O}_{2}$ concentration were made by Winkler's method. Until 1994 temperatures were measured using a multiparametric probe and a reverse thermometer; later a thermistor was used, to a depth of $50 \mathrm{~m}$, and a reverse thermometer.

The laboratory methods used to determine the different chemical variables were potentiometry for conductivity, molecular spectrometry for nitrates, ammonium, total nitrogen, reactive and total phosphorus and silicates, ion chromatography for sulfate, chloride, $\mathrm{Ca}, \mathrm{Mg}, \mathrm{Na}$ and $\mathrm{K}$, and potentiometric titration for alkalinity. For results obtained before 1997, see Garibaldi et al. (1997); from 1997 to 2003 data were again collected by Garibaldi and are reported in Salmaso et al. (2003). These results provide a complete picture of the chemical and physical situation of Lake Iseo from 1978 to 2003 as regards the early spring months (March, beginning of April), and for the years 1978, 1982 and 1984 and from 1994 to 2003 as regards the winter months of January and February. Note that measurements were taken monthly in 1978 and from 1993 to 2003.

Stability and heat content were assessed by means of some modifications to the LIMNOX program (kindly supplied by Bob Banens, University of New England, Armidale , NSW, Australia) introduced by A. Rolla (I.S.E Pallanza); this program is already a modified version of the LIMNO/2 program (Ferris 1989), which in its turn was a development of the original LIMNO program by Johnson et al (1978). In it Ferris develop a basic program for calculation of whole lake stability, heat content and volume-weighted averages of oxygen concentration and salinity. Further the Walker-modified stability (Walker 1974) for both "open" and "closed" meromictic lakes (Hutchinson 1957) is calculated in profile and as a whole lake total. The program envisages the conversion of conductivity to salinity and the additive contribution to density, due to salinity. The theoretic formulation of these parameters and their mathematical expression can be found in detail in Hutchinson (1957), Idso (1973), Walker (1974), Johnson et al. (1978, 1979) Viner (1984), Ferris \& Burton (1988). By applying this program we were able to determine for each date, in addition to the heat content, the thermal stability $\left(\mathrm{S}_{\mathrm{t}}\right)$ using temperature alone; conductivity values were also introduced to obtain total stability $\left(\mathrm{S}_{\mathrm{T}}\right)$. The difference between these two values is obviously chemical stability $\left(\mathrm{S}_{\mathrm{ch}}\right)$ This method of calculation also yields the distribution of stability along the depth at very small intervals $(10 \mathrm{~cm})$, as well as the values integrated on the whole water column, minimizing errors arising from the non-linearity of the relations between temperature, conductivity and density.

\section{RESULTS AND DISCUSSION}

\subsection{Stability on the whole water column}

The historical series of data referring to stability as an integrated value on the Lake Iseo water column (1973-3002) shows that both maximum and minimum values are progressively increasing, a trend which has been particularly marked since the $90 \mathrm{~s}$. In the years for which complete monthly data are available, the annual $\mathrm{S}_{\mathrm{T}}$ cycle has its lowest values in the first three months of the year and its highest values in August-September. The minimum values, usually in February, were between 150 and $300 \mathrm{~J} \mathrm{~m}^{-2}$ in the $70 \mathrm{~s}$ and $80 \mathrm{~s}$, with a strong increase (doubling or trebling the values) in the $90 \mathrm{~s}$, with a peak of $1,418 \mathrm{~J} \mathrm{~m}^{-2}$ measured in January 1997. The maximum values showed a similar increase, from around 18,000 $\mathrm{J} \mathrm{m}^{-2}$ in August 1978 to 28,000$29,000 \mathrm{~J} \mathrm{~m}^{-2}$ in the last few years $\left(29,401 \mathrm{~J} \mathrm{~m}^{-2}\right.$ in May 1998). The most marked increases and decreases were found respectively between May and June and between September and October, with values close to $11,000 \mathrm{~J}$ $\mathrm{m}^{-2}$; these "transitional periods" correspond to the onset of thermal stratification and destratification.

The high winter increase in $\mathrm{S}_{\mathrm{T}}$ found over the years within the water column is mainly due to the increase in solutes present in the deep hypolimnion. This is shown by conductivity, the mean values of which rose in this layer from around $250 \mu \mathrm{S} \mathrm{cm}^{-1}$ between 1978 and 1981 to $295 \mu \mathrm{S} \mathrm{cm}^{-1}$ in 2002 , and were actually in excess of $310 \mu \mathrm{S} \mathrm{cm}^{-1}$ in 1998. At least part of the $\mathrm{S}_{\mathrm{T}}$ increase, however, is due to the water temperature, which in the deepest layers rose from a minimum of $5.8^{\circ} \mathrm{C}$ in 1985 to a maximum of $6.7^{\circ} \mathrm{C}$ in 1999 . This increase in heat, which in addition was measured along the whole water column, means that due to the interplay of the densities an increase in work was required to mix the single layers, which raised the $S_{T}$ values, though to nothing like the same extent as the $\mathrm{S}_{\mathrm{T}}$ produced by dissolved solids.

It is thus the chemical component $\left(\mathrm{S}_{\mathrm{ch}}\right)$ that plays the major role in the late winter months. At this time of year the vertical heat gradient within the water column is very weak (only a few tenths of a degree) and, at least in theory, it would not be difficult for external agents to completely erode such a small gradient, resulting in a full circulation. However, this is precluded by the concentration of solutes present, especially in the 


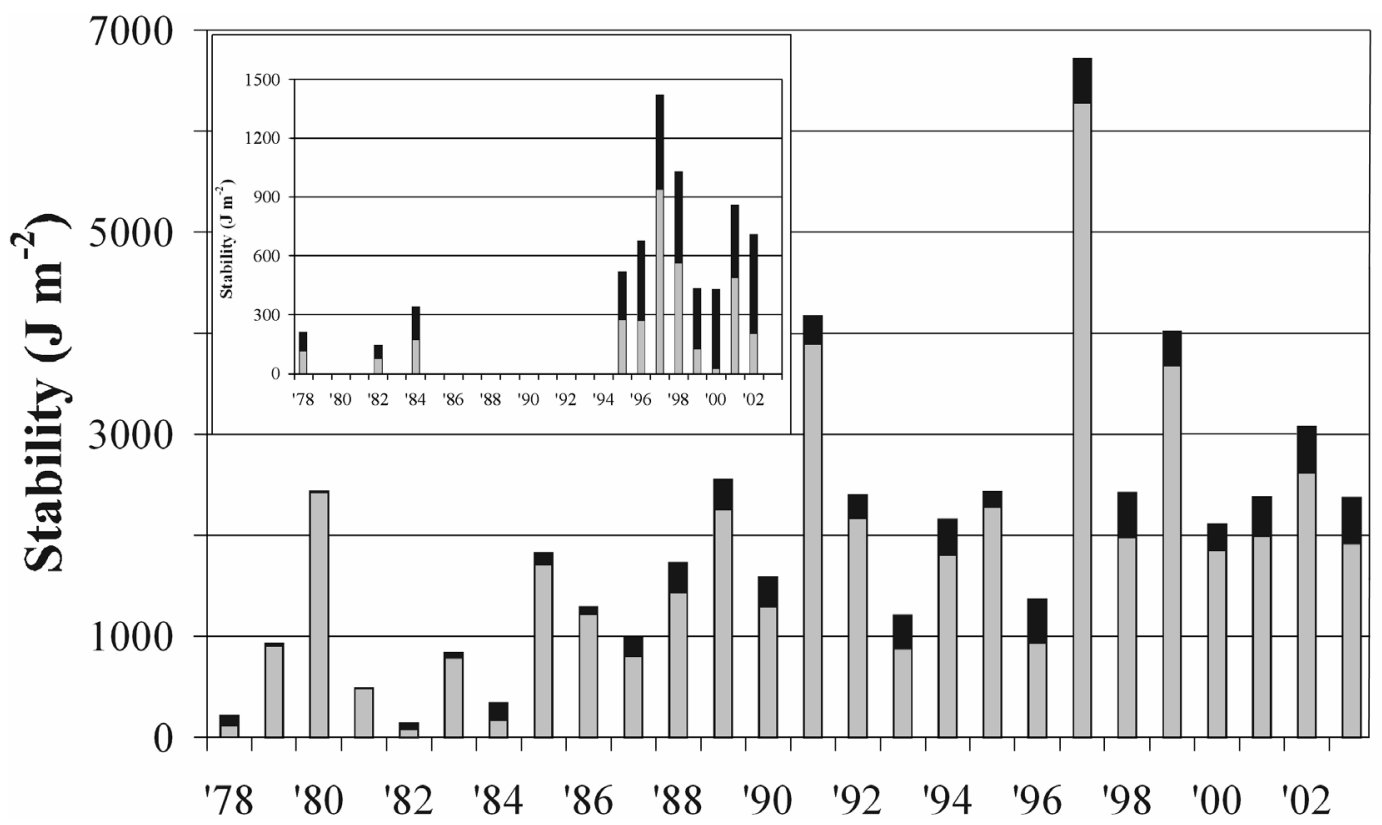

Fig. 2. Total stability as the result of the sum of thermal (grey bars) and chemical (black bars) stability in Lake Iseo for spring time. The insert shows the stability values for the winter.

deepest waters; these contribute to increasing the difference in density between the upper and the deep hypolimnion, conditioning the depth of the vertical mixing of the lake.

Of the two components of $S_{T}$, on the other hand, the thermal component $\left(\mathrm{S}_{\mathrm{t}}\right)$ has its highest values from May to October, so that it has a dominant role in these months, and can constitute more than $95 \%$ of total stability. Chemical stability on the other hand remains steady, with a $3-4 \%$ share of $\mathrm{S}_{\mathrm{T}}$, which means that it is altogether marginal from May to October, when it is overwhelmingly dominated by the stability determined by the thermal stratification.

The summer increase in total stability over the years must be seen, especially, in relation to the increase in the thickness of the surface water layer involved in the annual heat exchange. In fact, $90 \%$ of the energy exchange between 1977 and 1995 occurred within the top 45 meters, whereas in the years after 1995 this layer increased considerably, exceeding 90 meters depth and so involving around $60 \%$ of the lake's volume, compared with the $30 \%$ of the earlier period (Ambrosetti \& Barbanti 2002a). This has resulted in a considerable accumulation of energy, which has had a marked effect on the stability of the uppermost layers of the lake, with the heat budget doubling between 1977 and 2000 from $751 \mathrm{MJ} \mathrm{m}^{-2}$ to $1440 \mathrm{MJ} \mathrm{m}^{-2}$, albeit with a slight decrease in the years after 2000.

Figure 2 shows the quantities of $\mathrm{S}_{\mathrm{T}}, \mathrm{S}_{\mathrm{t}}$ and $\mathrm{S}_{\mathrm{ch}}$ evaluated for the period 1978-2003 at the start of the spring in each year, i.e. at the moment when the annual limnological cycle should be complete (or nearly so) with the establishment of partial or total vertical circulation; the inset figure shows the data referring to the measurements performed in winter (February). The data in the first series partly show the effect of the surface heating which has already begun: the $\mathrm{S}_{\mathrm{ch}}$ percentage of the $\mathrm{S}_{\mathrm{T}}$ is relatively low - a mean of $16 \%$ with a peak of $49 \%$ in 1984 . In contrast, the series of winter data shows the different influence of the chemical component on total stability; these data were collected at a time when the water column is close to isothermia. Until after the mid 70 s the chemical stability displayed values below $50 \%$ of total stability, reaching around $70 \%$ at the end of the $70 \mathrm{~s}$ and exceeding this percentage from 2000 on $(94.5 \%)$.

However, it must be stressed that in both series the trend is in the direction of a general increase, and that moreover the peaks of $\mathrm{S}_{\mathrm{T}}$ in the complete series (1991, 1997 and 1999) can be ascribed to an insufficient loss of the heat accumulated during the previous summer, following relatively warm autumns and winters.

\subsection{Mixing depth, oxygenation and chemical stability}

Figure 3 shows the trend of $S_{c h}$ integrated on the water column as well as the oxygen concentrations (mg $1^{-1}$ ) on the bottom and in the 150-250 m layer, and the mixing depths at the end of the limnological winter, for the period 1978-2003. The mixing depths, evaluated on the basis of the distribution of $\mathrm{O}_{2}$, conductivity and temperature concentrations along the whole Lake Iseo water column, are also shown in table 1.

The last complete vertical mixings occurred in 1979, 1980 and 1981. The 1981 event was induced by currents which were set up in the lake by wind from the north, i.e. along the main axis of the lake, driving the surface water to the downwind end and forcing it to sink and flow on the bottom in the opposite direction to the 


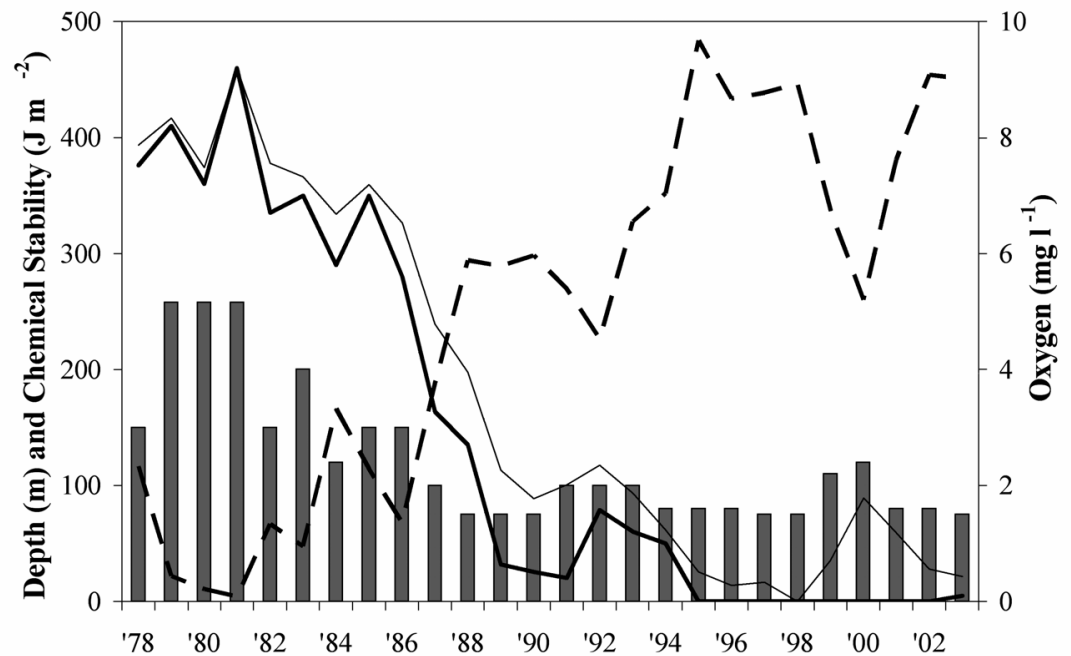

Fig. 3. Trends of $S_{c h}$ (dashed line), mixing depths (histograms), and oxygen concentrations in the 100-251 layer (thin line) and on the bottom (thick line) of Lake Iseo, measured at the end of the limnological winter in 1978-2003. The $\mathrm{O}_{2}$ concentrations refer to the right-hand $\mathrm{Y}$ axis.

Tab. 1. Winter mixing depths calculated on the basis of temperature, conductivity and $\mathrm{O}_{2}$ concentration values measured from surface to bottom in Lake Iseo.

\begin{tabular}{ccccc}
\hline Year & $\begin{array}{c}\mathrm{O}_{2} \\
\left(\mathrm{mg} \mathrm{l}^{-1}\right)\end{array}$ & $\begin{array}{c}\text { Cond. } \\
\left(\mu \mathrm{Sm}^{-1}\right)\end{array}$ & $\begin{array}{c}\text { temp. } \\
\left({ }^{\circ} \mathrm{C}\right)\end{array}$ & $\begin{array}{c}\text { Mix. Depth } \\
(\mathrm{m})\end{array}$ \\
\hline 1978 & 251 & 251 & $100-150$ & 150 \\
1979 & 251 & 251 & 75 & 251 \\
1980 & 251 & 251 & 251 & 251 \\
1981 & 251 & 251 & 251 & 251 \\
1982 & 150 & $150-200$ & $100-150$ & 150 \\
1983 & $150-251$ & $100-150$ & $150-251$ & 200 \\
1984 & $150-251$ & $100-150$ & 100 & 120 \\
1985 & $150-251$ & $100-150$ & $100-251$ & 150 \\
1986 & 150 & $100-150$ & $75-100$ & 150 \\
1987 & 100 & $75-100$ & 75 & 100 \\
1988 & 75 & 75 & $75-100$ & 75 \\
1989 & 75 & 75 & $75-100$ & 75 \\
1990 & $75-100$ & 75 & $75-100$ & 75 \\
1991 & $100-120$ & 100 & $75-100$ & 100 \\
1992 & 100 & 100 & 100 & 100 \\
1993 & 100 & $75-100$ & 75 & 100 \\
1994 & 100 & $75-100$ & $75-100$ & 80 \\
1995 & $75-100$ & $50-75$ & $100-120$ & 80 \\
1996 & 75 & $75-100$ & $75-100$ & 80 \\
1997 & 75 & $75-100$ & $75-100$ & 75 \\
1998 & 75 & $50-75$ & $75-100$ & 75 \\
1999 & $100-120$ & $100-120$ & $100-120$ & 110 \\
2000 & $100-150$ & $100-150$ & $100-150$ & 120 \\
2001 & $75-100$ & $75-100$ & $75-100$ & 80 \\
2002 & $100-150$ & $75-100$ & $75-100$ & 80 \\
2003 & 100 & 60 & 75 & 75 \\
\hline
\end{tabular}

upwind end, where it surfaced once again. This phenomenon amounts to nothing less than a conveyor belt circulation, which has been described in other deep lakes, both north and south of the Alps (Ambrosetti et al. 2003a; Ambrosetti et al. 1982). In fact, on this occasion, both in the surface and the deep layers of Lake Iseo, there was a very high, even concentration of oxygen and solutes, in any case higher than the concentration in the intermediate layer; the subsequent erosion of this layer through convection led to a complete homogenization of the entire water mass of the lake. Some doubts remain as to the depths reached by the type of vertical mixing which occurred from 1983 to 1985 , because of the high $\mathrm{O}_{2}$ concentration found on the bottom, although it did not reach the 1981 values. The situation of Lake Iseo at the edge of 


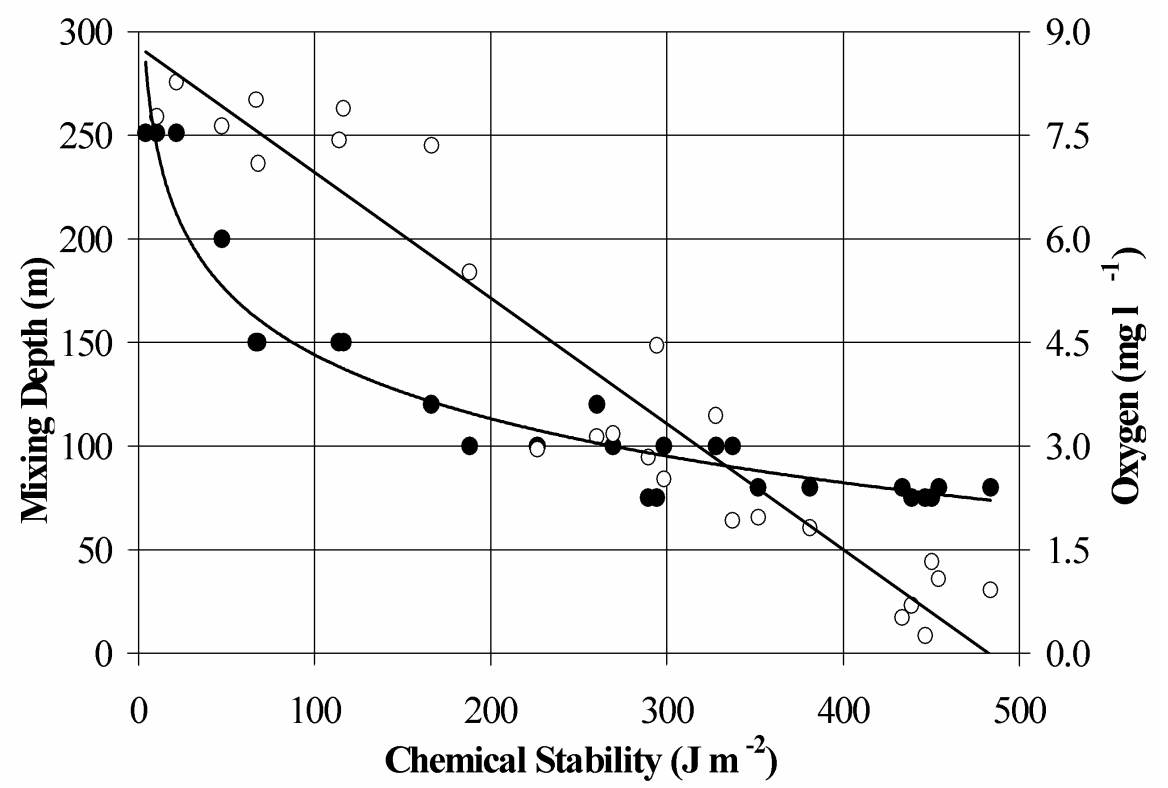

Fig. 4. Regression curve between $\mathrm{S}_{\mathrm{ch}}$ and mixing depth (black dots), represented by the equation $\mathrm{y}=-44.57 \mathrm{Ln}(\mathrm{x})+349.37\left(\mathrm{R}^{2}=\right.$ 0.93 ) and regression line between $\mathrm{S}_{\mathrm{ch}}$ and $\mathrm{O}_{2}$ concentration (white dots) represented by the equation $\mathrm{y}=-0.0182+8.78\left(\mathrm{R}^{2}=0.92\right)$.

mountain ranges determined an influx of cold, welloxygenated river water to the lake from the late winter or spring snowmelt, which sank to the maximum depth. This is a characteristic phenomenon which is regularly found also in lakes Maggiore and Como; like Iseo, they are deep lakes of fluvial origin with subsequent glacial excavation (Ambrosetti \& Barbanti 2003; Sossau \& Pechlander 1988; Meybeck et al. 1991).

From 1986 to 2003 the deep waters of Lake Iseo were subjected to a long period of isolation when (as also happened in the other subalpine lakes) the mixing depths induced by convective motions did not exceed 100-120 meters, although sometimes (for instance in 1999 and 2000) the water layers were characterized by a small degree of oxygenation, at least to a depth of 200 m.

The chemical stability of Lake Iseo increased considerably in 1978-2003, but now shows a contrary trend both to that of $\mathrm{O}_{2}$ concentration and to that of mixing depths. The succession of increases and decreases (of which the latter are not able to counter the positive trend) coincides exactly with certain meteorological and hydrological events which have affected the catchment area. Nevertheless, these events have not been enough to alter the situation of meromixis in the lake. The event of 2000 was typical: the oxygen increase produced a distinct downturn in the increasing trend of $\mathrm{S}_{\mathrm{ch}}$, but there was no replenishment of $\mathrm{O}_{2}$ in the lowest levels (Fig. 3), and the lake's evolution towards meromixis merely dipped slightly, to resume again immediately in 2001.

In Lake Iseo the anoxia of the deepest layers that occurred after 1994 indicates that the high density of these layers, the result of a high concentration of dissolved solids, is such that in late winter or spring it prevents inflowing water from penetrating these levels and reaching the bottom. Nevertheless, this process did occur during the same years in the other deep sudalpine lakes with similar morphometric characteristics. Clearly it was precisely this increase in stability in the hypolimnetic waters of Lake Iseo that prevented the deep layers from being replenished with new water, a process that occurred frequently in the past, compensating for the absence of holomixis. This state of affairs is alarming for the evolution of the lake, which will inevitably proceed towards a more advanced stage of meromixis. A further deterioration of this kind is quite likely, as there is no mechanism within or outside the lake, as far as we know, able to provide sufficient energy to remove the layer of stagnant water on the bottom, obviously apart from hydro-meteorological events of exceptional impact, which however would have only a temporary mitigating effect on the deterioration of the water.

By looking at the values of $\mathrm{S}_{\mathrm{ch}}$ on the whole column, therefore, we can not only analyze and quantify the development of the meromictic state of a lake, but also identify the mechanisms regulating its positive or negative evolution, and evaluate how these mechanisms can occur within the water mass. The same considerations can also be made by analyzing the heat content in lakes not affected by solute redistribution (Ambrosetti et al. 2003b).

On the other hand, the statistical correlations between $\mathrm{S}_{\mathrm{ch}}$ and $\mathrm{O}_{2}$ (highlighted in figure 4 by the regression line) and between $\mathrm{S}_{\mathrm{ch}}$ and mixing depth (regression curve) are both highly significant, indicating that chemical stability within the whole column is a 


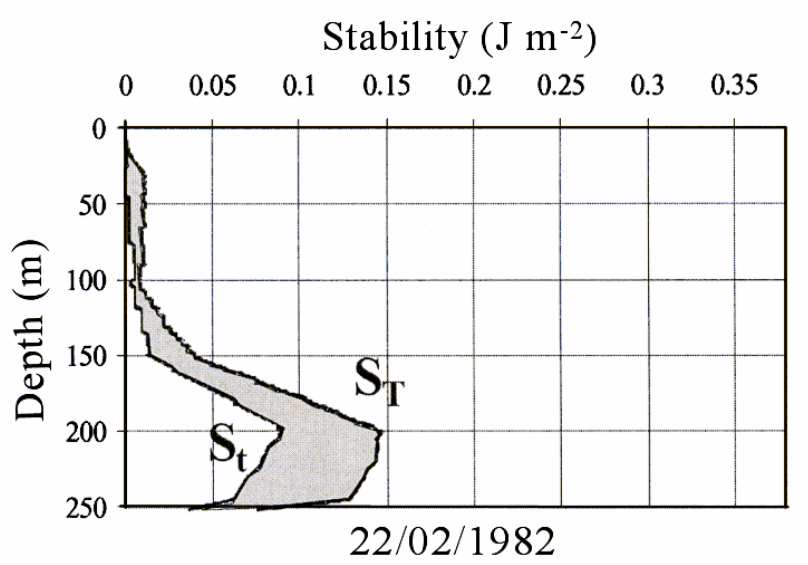

Stability $\left(\mathrm{J} \mathrm{m}^{-2}\right)$

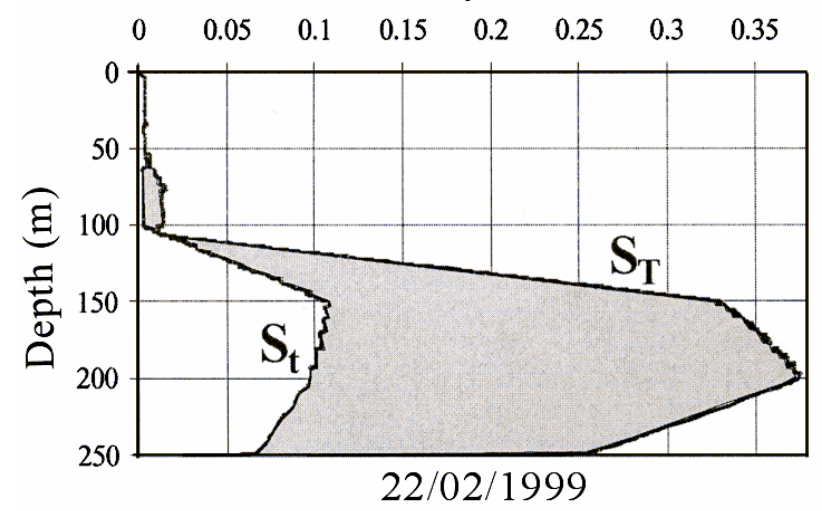

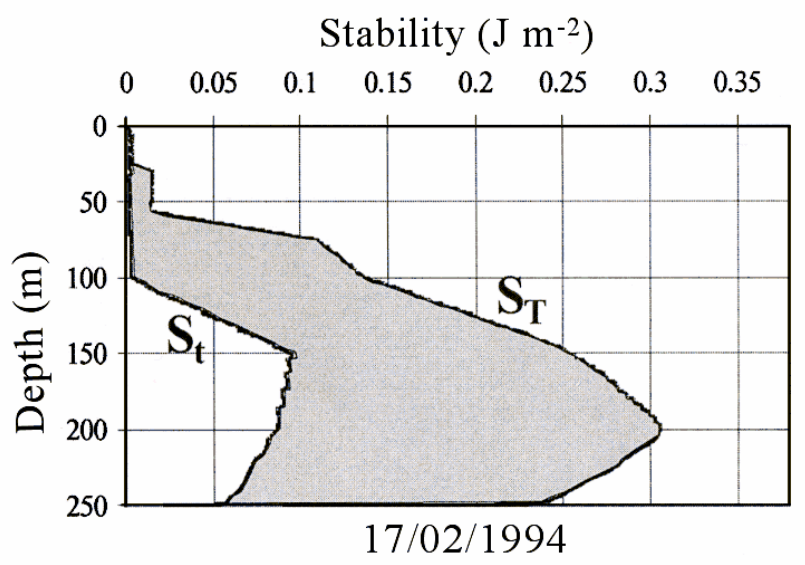

Stability $\left(\mathrm{J} \mathrm{m}^{-2}\right)$

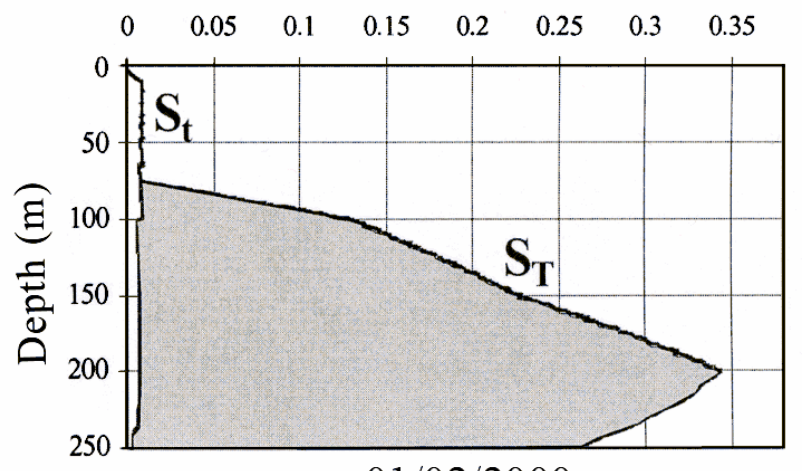

$01 / 02 / 2000$

Fig. 5. Vertical distribution in Lake Iseo of total stability $\left(\mathbf{S}_{\mathbf{T}}\right)$, thermal stability $\left(\mathbf{S}_{\mathbf{t}}\right)$ and chemical stability (shaded area) in some winter months in the period 1978-2003.

clear index of the lake's status and also of the depth reached by the late winter vertical circulation.

As regards the relationship between $\mathrm{S}_{\mathrm{ch}}$ and oxygen concentration, the points which are most distant from the regression line are those referring to the years before 1994, when complete mixing processes were frequent or the water conveyed by the tributaries was able to reach the bottom, as occurred in 1992, or else (1988) when a decrease in $\mathrm{O}_{2}$ corresponds to an increase in $\mathrm{S}_{\mathrm{ch}}$, following the occurrence over many years of vertical circulations of very limited depth.

\subsection{Vertical distribution of $S_{T}, S_{t}$ and $S_{c h}$}

The evolution of Lake Iseo towards a state of meromixis from 1981 to 2003 can also be followed by observing the vertical distributions of the values of stability in its three components, in the same way as the totals on the column. The winter distributions provide a clear picture of the deep water layers that are most resistant to mixing, allowing us to verify the hydrodynamic mechanisms occurring within the water mass.

In the last year that the lake underwent a complete mixing (1981), not only was the oxygenation almost perfect, but the $\mathrm{S}_{\mathrm{T}}$ value on the whole column was also one of the lowest between 1978 and 2003 (487 $\mathrm{J} \mathrm{m}^{-2}$ ), while the vertical circulation of the water reached the maximum depth. Furthermore, the $\mathrm{S}_{\mathrm{T}}$ distribution within the column coincided almost exactly with that of $\mathrm{S}_{\mathrm{t}}$, so that the influence of the chemical component was almost insignificant $\left(4.2 \mathrm{~J} \mathrm{~m}^{-2}\right)$, corresponding to $0.8 \%$ of the total stability and with a maximum resistance due to $S_{\mathrm{ch}}$ of only $0.01 \mathrm{~J} \mathrm{~m}^{-2}$ at a depth of $240 \mathrm{~m}$.

In contrast, the vertical distribution of the three components of stability in the winter months of some of the last 25 years (Fig. 5) reveals that since 1982 the area defined between the $S_{T}$ and $S_{t}$ profiles, i.e. $S_{c h}$, has seen a conspicuous increase in value, taking on an increasingly decisive role in preventing the vertical mixing of the water mass. In fact, the volumes of water below a depth of $100-150 \mathrm{~m}$ in $1982,60-80 \mathrm{~m}$ in 1994 , $110 \mathrm{~m}$ in 1999 and $80-100 \mathrm{~m}$ in 2000 , present an increasingly high chemical concentration, so that they are extremely stable; the upper limit of these volumes corresponds exactly to the depth reached by the winter circulation induced by convective motions. At the same time, the level at which the maximum $S_{T}$ is found remains almost constantly at a depth of around $200 \mathrm{~m}$, 
while the maximum $\mathrm{S}_{\mathrm{t}}$ values, all between 0.09 and 0.1 $\mathrm{J} \mathrm{m}^{-2}$, are at a variable depth; in $2000 \mathrm{~S}_{\mathrm{t}}$ does not exceed $0.01 \mathrm{~J} \mathrm{~m}^{-2}$, but this is due to the cooling caused on the whole column by water sinking to a depth of $200 \mathrm{~m}$.

The levels at which the chemical stability reaches its highest values tend however as the years go by to shift upwards and increase progressively in value. This means that an action is in progress which starting from below tends to involve a larger and larger volume of water, thus also increasing stability. In fact, the maximum resistance due to the solutes present, from $240 \mathrm{~m}$ in 1981 and from $235 \mathrm{~m}$ in 1982, rises gradually to $195 \mathrm{~m}$ in 2002 with $\mathrm{S}_{\mathrm{ch}}$ presenting a value of $0.37 \mathrm{~J}$ $\mathrm{m}^{-2}$; at the same time, at the same level the highest value of total stability $\left(0.47 \mathrm{~J} \mathrm{~m}^{-2}\right)$ for all of the period under consideration was recorded.

The increasing importance of $\mathrm{S}_{\mathrm{ch}}$ in Lake Iseo emerges from the following data:

- in $1981, \mathrm{~S}_{\mathrm{ch}}$ was little more than $5 \%$ of $\mathrm{S}_{\mathrm{T}}$ in the layer below $210 \mathrm{~m}$;

- in 1982, the year in which the process of oligomixis began, $\mathrm{S}_{\mathrm{T}}$ in the layer below 150 meters was $45 \%$ of the total;

in 2000, with the monimolimnion between -100 and the bottom, corresponding to around $50 \%$ of the total volume of the lake involved in meromictic processes, $\mathrm{S}_{\mathrm{ch}}$ represented around $97 \%$ of total stability;

in 2002 , below 80 meters, $S_{c h}$ comprised $76 \%$ of total stability but involved a water volume greater than $50 \%$ of the volume of the whole lake.

\subsection{Vertical distribution of chemical stability and meromixis}

The variation of the vertical distribution of $\mathrm{S}_{\mathrm{ch}}$, as emerges from the situation found at the end of the limnological year in the last 25 years, deserves more detailed analysis (Fig. 6). The relative curves reflect the continuous increase in the chemical stratification of the lake water and highlight the fact that since the 80 s the state of meromixis has become increasingly stable. In this process three time phases can be identified.

The first phase was before 1981, when the processes of holomixis were frequent (3 occurred between 1978 and 1981) and there was a good degree of oxygenation of the deep waters; the result was low $\mathrm{S}_{\mathrm{T}}$ values on the whole column (as described above), but above all the fact that $S_{\text {ch }}$ did not exceed $0.01 \mathrm{~J} \mathrm{~m}^{-2}$ at the various levels. The sole exception in an almost constant trend was the year 1978 , when at $-230 \mathrm{~m}$ there was a $\mathrm{S}_{\mathrm{ch}}$ value of $0.14 \mathrm{~J} \mathrm{~m}^{-2}$, which may be attributed to the fact that on this occasion the vertical mixing induced by convective motions did not exceed $150 \mathrm{~m}$. Nevertheless, the sinking of water to the deep layers resulted in deep oxygenation and homogenization of conductivity, but not a vertical isothermia; in fact, between the depths of 100 and 150 $\mathrm{m}$ there was still a slight thermal gradient of $0.05-0.1$
${ }^{\circ} \mathrm{C}$, a difference more than adequate in a deep lake like Iseo to prevent a full circulation, also considering the increase in density caused by the hydrostatic pressure of the water column. The data shown in the figure support the affirmation that when at the end of winter there is still a level below a depth of $50 \mathrm{~m}$ with stability greater than $0.02 \mathrm{~J} \mathrm{~m}^{-2}$, complete circulation does not occur.

In the second stage, up to 1994, the vertical mixing was only of the oligomictic type (though this is not entirely certain for 1983), and the vertical circulation reached a maximum depth of $200 \mathrm{~m}$. However, in all of these years there was a considerable increase in the area bounded by the $\mathrm{S}_{\mathrm{ch}}$ curves, and the peak $\left(0.23 \mathrm{~J} \mathrm{~m}^{-2}\right)$ was measured in 1994 at a depth of $205 \mathrm{~m}$. It was in fact in August 1994 that Garibaldi et al. (1997) first recorded conditions of anoxia at the bottom of the lake.

In the third phase the vertical convective mixing reached a maximum depth of 100-120 m (1999 and 2000); the logical consequence of this was a state of stagnation of the deep waters, due primarily to the quantity of solutes present, with a consequent conspicuous increase in chemical stability, especially from a depth of 200 meters. After 1999, values well in excess of $0.3 \mathrm{~J} \mathrm{~m}^{-2}$ were found at these levels, with an increasingly large area bounded by the $\mathrm{S}_{\mathrm{ch}}$, curve. The chemical stability even in the layer between 50 and 120 meters was as high as $0.2 \mathrm{~J} \mathrm{~m}^{-2}$; such values were found before 1995 only at a depth of 200 meters. There is an evident effect of the steady increase in the quantity of dissolved solutes in the deep water mass, but also the strong growth of the percentage of water volume involved in an increase of stability.

In discussing the biogeochemical processes underlying the solute increase, it should be remembered that calcium $\left(2.19 \mathrm{meq}^{-1}\right)$ and bicarbonate $(1.89 \mathrm{meq}$ $1^{-1}$ ) dominate the ion spectrum in Lake Iseo, followed by magnesium and sulfates $\left(0.67\right.$ and 1.04 meq $1^{-1}$ respectively); these ions make up $95 \%$ of the whole solute content (Garibaldi et al. 1977). The presence of anhydrides in the watershed of the lake means that the sulfate concentrations are relatively high compared with the other deep subalpine lakes, where there is a variation between 0.23 and $0.61 \mathrm{meq}^{-1}$, for lakes Garda and Maggiore respectively.

In particular, Lake Iseo is affected by a chemical process which is also seen in Lake Idro (Garibaldi et al. 1997): the precipitation and redissolution of $\mathrm{CaCO}_{3}$ with the transfer of ions, primarily $\mathrm{Ca}$ and bicarbonate, from the surface water to the hypolimnion. This contributes to the creation of a marked density gradient between the two water layers; the process is facilitated by the high $\mathrm{pH}$ values, normally between 7.6 and 8.0, with peaks of 9.0 during the most intense episodes of algal productivity.

If we look at the values of alkalinity, calcium and conductivity (the last used as an estimate of the solute concentration) over time, there is clearly a progressive 

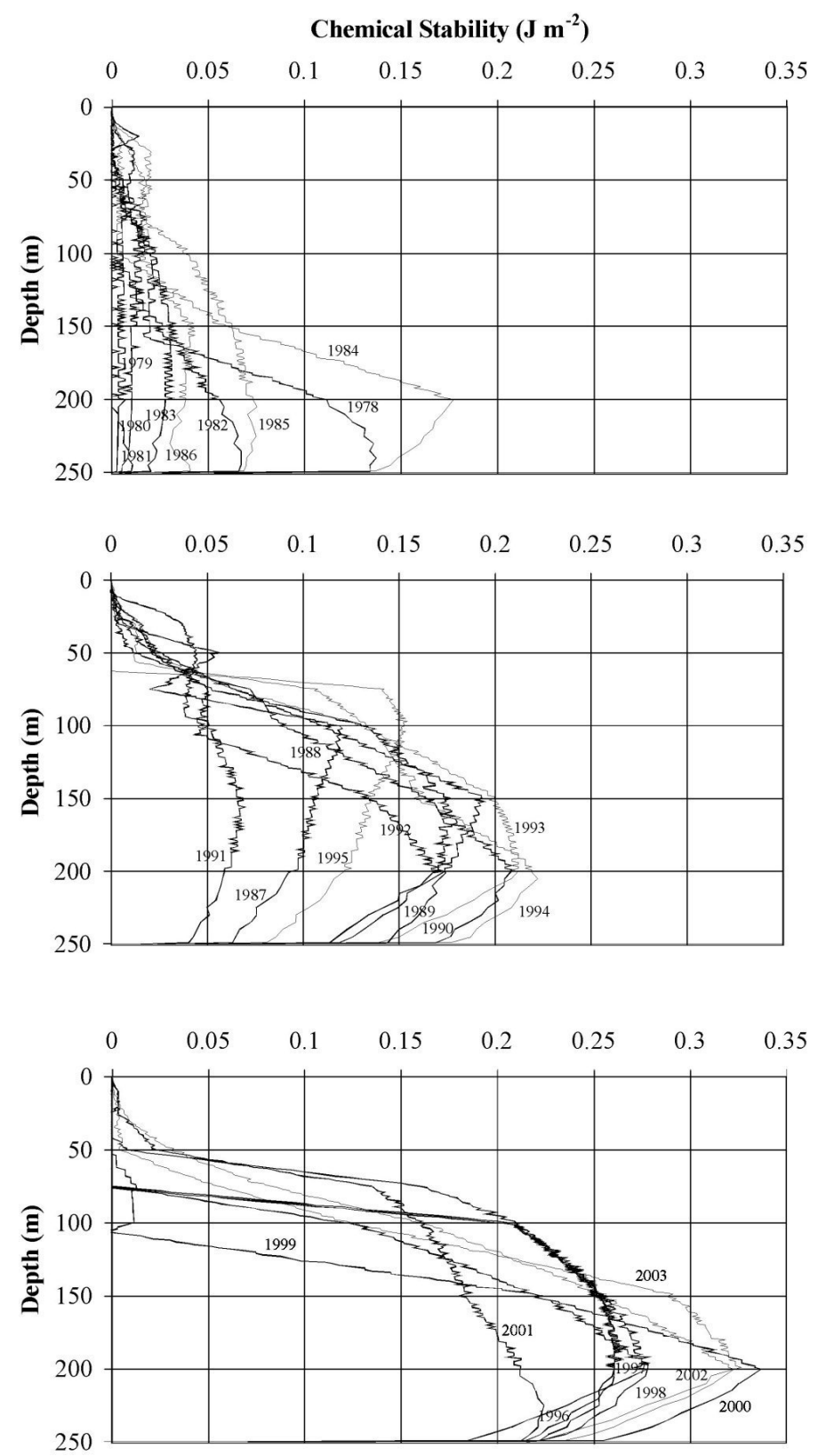

Fig. 6. Vertical distribution of $S_{\text {ch }}$, in Lake Iseo at the end of the limnological winter from 1978 to 2003.

increase in mean solute concentrations below a depth of $100 \mathrm{~m}$, with a consequent rise in density for the ions in solution, from $220 \mathrm{mg} \mathrm{l}^{-1}$ in 1981, to $238 \mathrm{mg} \mathrm{l}^{-1}$ in 1993, and $250 \mathrm{mg} \mathrm{l}^{-1}$ in 2002 .

\section{CONCLUSIONS}

Lake Iseo should not be regarded as a stably meromictic lake in the same category as lakes Idro and Lugano, which are deep subalpine lakes $\left(\mathrm{z}_{\max } 120\right.$ and $288 \mathrm{~m}$ respectively) with a monimolimnion permanently prevented from circulating by the presence of a strong, stable chemocline which marks a sharp change from the lighter to the heavier water layer. However, there is no doubt that Lake Iseo is at the culmination of a stage of evolution leading towards meromixis, even though the vertical distinction between the layers is not yet so sharp. The most recent stability values, and especially the lake's evolutionary trend, suggest that its chemical stratification is becoming increasingly marked and is rising continuously. Certainly this process is also conditioned by the major climatic changes which are currently affecting our latitudes, especially in winter, and whose variations contribute to the stabilization of the deep layers (Ambrosetti \& Barbanti 2000). While it is not difficult to identify the progressive increase in solute concentrations as the prime cause of the evolution of Lake Iseo towards meromixis, there is also the fact that the anoxia of the deepest layers was measured for the first time (in 1994) when the water mass had already 
been undergoing only partial vertical circulations for more than ten years.

We may therefore reasonably hypothesize a synergic effect, a simultaneous action of two phenomena, one physical and one chemical, on the water of the lake, which has enhanced the effects deriving from each phenomenon. These are the isolation of the deep layers, as the prime consequence of the increase of dissolved solutes, and the limited depth reached by the winter mixing, which in turn is closely dependent on the meteorological conditions prevailing on the area of the lake and its watershed.

With the increasing density of the deep layers, in fact, the winter destabilizing effect produced by the action of external forces (i.e. the kinetic energy required for a complete mixing, sufficient to overcome the chemical stratification present) has not been occurring, at the very moment when the so-called "new water" is being formed, with the result that the deep water is becoming stabilized over time (Ambrosetti et al. 2003a; Ambrosetti \& Barbanti 2000).

The external energy available for the destratification process through convective motions, necessary for a deep circulation, has effectively decreased over the last twenty years, and has been quantified in the formulation of a parameter M by Ambrosetti \& Barbanti (1999). This parameter is used to evaluate the depth reached by the late winter vertical mixing, by taking into consideration the wind run, the difference between air and surface water temperature, and the solar radiation in the appropriately weighted winter months. The analysis of this parameter, evaluated for a long period on Lake Maggiore (1956-2003) and for shorter periods on other deep lakes (including Iseo; Ambrosetti et al. 1982) has highlighted the fact that the meteorological conditions in the coldest months of the year in each area have been gradually changing, particularly with a rise in atmospheric temperature, especially in its minimum values, and with a decline in wind energy.

At a hydrodynamic level, these variations mean that extra energy is required for a complete mixing of the water to take place. This is confirmed by measuring the quantity of Birgean work (defined as the set of factors acting on the distribution of energy within a lake rather than the action of the wind alone): this parameter increased from $1978\left(8.9 \mathrm{~J} \mathrm{~m}^{-2}\right)$ to $2003\left(663 \mathrm{~J} \mathrm{~m}^{-2}\right)$ with a similar trend to that of stability, i.e. a rise over time of all its components (total, thermal and chemical stability).

The increases in energy of the deep hypolimnion can also be shown by analyzing the "climatic memory" (Ambrosetti et al. 1999), a characteristic of this layer in lakes. We did in fact find that the main hydrodynamic processes in the deep sudalpine waterbodies develop simultaneously, show the same trends, and have a similar configuration; this means that the hydrometeorological events have occurred in the same way in all the lakes in the sud-alpine district, as a consequence of meteorological situations evolving on a wide scale and which may be interpreted in the light of ongoing climate changes. However, the presence in Lake Iseo over the years of a high and ever-increasing hypolimnetic density has limited the efficacy of these events, preventing the inflowing water from reaching the bottom of the lake.

Another hydrodynamic aspect of prime importance for the lake ecosystem which is changing due to the lack of mixing and homogenization of the water column, is the water renewal time. The isolation of the deep hypolimnion, which as we have seen has lasted for many years in Lake Iseo, has profound repercussions on the actual renewal time of its water, which is showing an increasing divergence from the theoretical renewal time.

Furthermore, a smaller fraction of matter can now be recycled from the deep layers towards the surface layers, which merely increases the density of these layers, facilitating the stagnation of the deep water and the consequent process of meromixis, which is becoming increasingly marked and stable.

But the interannual variability of the depth reached by the winter mixing is also having a considerable effect on the biology of the lake ecosystem. Salmaso et al. (2003) recognized the major impact of meteo-climatic changes on the variations which have occurred in the dominant groups of phytoplankton in Lake Iseo. It is not merely a question of variations in meteorological conditions during the whole vegetative cycle; there has also been a change in the winter and spring circulatory processes which condition the pool of nutrients recycled from the deep layers towards the surface. Again, Salmaso et al. (2003) emphasize that in conditions of meromixis, the renewal time of the hypolimnetic waters is short, favoring an increase in algal nutrients, as well as dissolution of $\mathrm{CaCO}_{3}$ from settling particles, with a corresponding increase in water density.

\section{ACKNOWLEDGMENTS}

We are grateful to Letizia Garibaldi (Dept. of Territorial and Environmental Science, University of Milan, Italy) and Rosario Mosello (C.N.R.- Institute for Ecosystem Study, Italy), for providing the physical and chemical data measured in Lake Iseo waters used in this paper; to Oscar Ravera, Riccardo de Bernardi and Rosario Mosello for revising the manuscript; to Bob Banens (University of New England, Armidale NSW, Australia), John Ferris (University of Adelaide and University of Tasmania) and Angelo Rolla (C.N.R.Istituto per lo Studio degli Ecosistemi, Italy) for devising and modifying the LIMNO program.

\section{REFERENCES}

Ambrosetti, W. \& L. Barbanti. 1999. Deep water warming in lakes: an indicator of climate change. J. Limnol., 58(1): 1-9. 
Ambrosetti,W. \& L. Barbanti. 2000. Riscaldamento delle acque profonde nei laghi italiani: un indicatore di cambiamenti climatici. Acqua \& Aria, 4: 65-72.

Ambrosetti, W. \& L. Barbanti. 2002a. Physical limnology of Italian lakes. 1 Relationship between morphometry and heat content. J. Limnol., 61(2): 147-157.

Ambrosetti, W. \& L. Barbanti. 2002b. Physical limnology of Italian lakes. 2. Relationships between morphometric parameters, stability and Birgean work. J. Limnol., 61(2): 159-167.

Ambrosetti, W., L. Barbanti \& R. Mosello. 1982. Unusual deep mixing of Lago Maggiore during the winter 19801981. Geogr. Fis. Dinam. Quat., 5: 183-191.

Ambrosetti, W., L. Barbanti \& A. Rolla. 2003b. Osservazioni sull'idrodinamica del lago. In: C.N.R. Istituto Italiano di Idrobiologia (Ed.). Ricerche sull'evoluzione del Lago Maggiore. Aspetti limnologici. Campagna 2002 e Rapporto quinquennale 1998-2002. Commissione Internazionale per la protezione delle acque italo-svizzere: 110-120.

Ambrosetti, W., L. Barbanti \& N. Sala. 2003a. Residence time and physical processes in lakes. J. Limnol., 62 (1): 1-15.

Ambrosetti, W., L. Barbanti, R. Mosello, A. Rolla \& D. Ruggiu. 1983. Mescolamento, caratteristiche chimiche, fitoplancton e situazione trofica nei laghi profondi sudalpini. C.N.R., P.F. "Promozione della qualità dell'ambiente", AQ/2/20: 151 pp.

Barbanti L. \& W. Ambrosetti. 1986. Energia termica e stabilità meccanica nel Lago Maggiore. Atti del $7^{\circ}$ congresso A.I.O.L.: 119-132.

Biswas, S. 1977. Thermal stability and phytoplankton in Volta Lake Ghana. Hydrobiologia, 56: 195-198.

Bonomi, G. \& M. Gerletti. 1967 Il Lago d'Iseo: primo quadro limnologico generale (termica, chimica. Plancton, e bentos profondo). Mem. Ist. ital. Idrobiol., 22: 149-175.

Bowling, L.C. 1990. Heat contents, thermal stabilities and Birgean wind work in dystrophic Tasmania lakes and reservoir. Austr.J. Mar. Freshw. Res., 41: 429-441.

Bowilng, L.C. \& K. Salonen. 1990. Heat uptake and resistance to mixing in small humic forest lakes in Southern Finland. Aust. J. Freshw. Res., 41: 747-759.

Ferris, J.M. \& H.R. Burton. 1988. The annual cycle of heat content and mechanical stability of hypersaline Deep Lake, Vestfold Hills. Antarctica. Hydrobiologia, 165: 115128.

Ferris, J.M. 1989. LIMNO/2 A basic program for calculation of whole lake stability, heat content and volume-weighted averages of oxygen concentration and salinity. Anare Research notes, 68: $22 \mathrm{pp}$.

Garibaldi, L. M. Brizzio, V. Mezzanotte, A. Varallo \& R. Mosello. 1995. The continuing evolution of Lago d'Iseo (N. Italy): the appearance of anoxia. Mem. Ist. ital. Idrobiol., 53: 191-212.

Garibaldi, L. M. Brizzio, V. Mezzanotte, A. Varallo \& R. Mosello. 1997. Evoluzione idrochimica e trofica del Lago d'Iseo. Documenta Ist. ital. Idrobiol., 61: 35-151.

Geller, W. 1992. The temperature stratification an related characteristic of Chilean lakes in mid summer. Aquatic Sci., 54(1): 37-57.

Guilizzoni, P., G. Bonomi, G. Galanti \& D. Ruggiu. 1982 Basic trophic status and recent development of some
Italian lakes as revealed by plant pigments and other chemical compound in sediment core. Mem. Ist. ital. Idrobiol., 40: 79-98.

Guilizzoni, P., G. Bonomi, G. Galanti \& D. Ruggiu. 1983. Relationship between sedimentary pigments and primary production: evidence from core analyses of twelve Italian lakes. Hydrobiologia, 103: 103-106.

Henry, R. \& F.A.R. Barbosa. 1989. Thermal structure, heat content and stability of two lakes in the National Park of Rio Doce Valley (Minas Gerais, Brasil). Hydrobiologia, 171: 189-199.

Hutchinson, G.E. 1957. A treatise on limnology. Vol. 1. John Wiley and Sons, New York: 1015pp.

Idso, S.B. 1973. On the concept of lake stability. Limnol. Oceanogr., 18: 681-683.

Johnson, N.M \& D.H. Merrit. 1979. Convective and advective circulation of Lake Powell, Utah-Arizona, during 19721975. Water Resour. Res., 15: 873-884.

Johnson, N.M., J.E. Eaton \& J.E. Richey. 1978. Analysis of five North American lake ecosystems. II. Thermal energy and mechanical stability. Verh. int. Ver. Limnol., 20: 562567.

Kjensmo, J. 1994. Internal energy, the work of the wind and the thermal stability in Lake Tyrifjord, southeastern Norway. Hydrobiologia, 286: 53-59.

Kling, G.W. 1988. Comparative trasparency, depth of mixing and stability of stratification in lakes of Cameroon, West Africa. Limnol. Oceanogr., 33: 27-40.

Loranger.T.J. \& D.F. Brakke. 1988. Birgean heat budgets and rates of heat uptake in two monomictic lakes. Hydrobiologia, 160: 123-127.

Mackey, A.P. 1991. Aspect of the limnology of Yeppen Lagoon Central Queensland. Austr. J. Mar. Freshw. Res., 42: 309-325.

Marchetto, A. \& R. Bettinetti. 1994. Reconstruction of phosphorus history from sedimentary diatoms of two deeps subalpine italian lakes, compared with long-term chemical measurement. Mem. Ist. ital. Idrobiol., 53: 2738.

Meybeck, M., Blanc, A.E. Moulherac \& C. Corvi. 1991. Chemical evidence of water movements in the deepest part of Lake Leman (Lake Geneva). Aquatic Science, 53/4: 273-289.

Salmaso, N., R. Mosello, L. Garibaldi, F. Decet, M.C. Brizzio \& P. Cordella. 2003. Vertical mixing as a determinant of trophic status in deep lakes: a case study from two lakes south the Alps (Lake Garda and Lake Iseo). J.Limnol., 62 (Suppl. 1): 33-41.

Sossau, C. \& R. Pechlaner. 1988. The regained, but hidden holomixis of the Austrian Lake Traunsee. Verh. int. Ver. Limnol., 23: 74-79.

Viner, A.B. 1984. Resistance to mixing in New Zealand lakes. N. Z. J. Mar. Freshwat. Res., 18: 73-82.

Walker, K.F. 1974. The stability of meromictic lakes in central Washington. Limnol. Oceanogr., 19: 209-222.

Wüest, A., G. Piepke \& J.D. Halfman 1996. Combined effects of dissolved solids and temperature on the density stratification of lake Malawi. In: Johnson, T.C. \& E.O. Odada (Eds), The limnology, Climatology and Paleoclimatology of East African Lakes. Gordon and Breach, Toronto: 183-202. 